Scientific Journal of Silesian University of Technology. Series Transport Zeszyty Naukowe Politechniki Śląskiej. Seria Transport

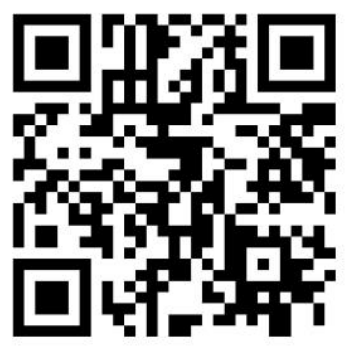

Volume 114

2022

p-ISSN: 0209-3324

e-ISSN: 2450-1549

DOI: https://doi.org/10.20858/sjsutst.2022.114.17

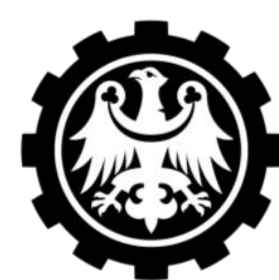

Silesian

University of Technology

Journal homepage: http://sjsutst.polsl.pl

Article citation information:

Żabówka, R., Maciuk, K. Impact of the COVID-19 pandemic on real estate market in Cracow. Scientific Journal of Silesian University of Technology. Series Transport. 2022, 114, 211-224. ISSN: 0209-3324. DOI: https://doi.org/10.20858/sjsutst.2022.114.17.

Rafal ŻABÓWKA ${ }^{1}$, Kamil MACIUK ${ }^{2}$

\title{
IMPACT OF THE COVID-19 PANDEMIC ON REAL ESTATE MARKET IN CRACOW
}

Summary. The purpose of this study was to determine the impact of the COVID19 pandemic on the Cracow real estate market. The data used in the study included transactions of purchase of flats and single-family houses. At the initial stage, the database was reduced by applying a four-step selection and outliers were removed. The data analysis included separate transactions for single-family houses and flats, 5 different types of charts were prepared for each type of real estate. The conducted research concerned: the analysis of the number of transactions in subsequent years, the share of the number of transactions in individual quarters, average transaction prices (for houses) or average prices per square meter (for flats), analysis of the number of transactions in individual districts, years and quarters, and a comparison of the number of contracts in individual quarters given years. The main conclusion drawn from the study is the significant impact of COVID-19 on the number of house and apartment purchase transactions, while the pandemic did not have a significant impact on the average prices in the analysed database.

Keywords: COVID-19, real estate, impact, trading

\footnotetext{
1 AGH University of Science and Technology, Mickiewicza 30 Av, 30059 Cracow, Poland. Email: floorball.rafal97@gmail.com. ORCID: https://orcid.org/0000-0003-1526-4255

2 AGH University of Science and Technology, Mickiewicza 30 Av, 30059 Cracow, Poland. Email: maciuk@agh.edu.pl. ORCID: https://orcid.org/0000-0001-5514-8510
} 


\section{INTRODUCTION}

In 2020 Poland, Europe, and the whole world pandemic mastered crown virus COVID-19. COVID-19 and its effects are very dangerous that society, spreads it by droplet, and so while talking, coughing, or sneezing, and symptoms are similar the common cold, which makes it difficult to detect correctly. The virus can be asymptomatic, but it can even cause death or other serious damage to health. World statistics (as of 02/01/2021) say about 85 million infections and 1.8 million deaths (Kostyńska 2020). The whole situation had a strong impact on many economic areas, both in the country and in the world. This had a direct impact on the decline in GDP. In Poland, a decline in GDP is forecasted at 4.5\% compared to 2019. Then, in 2021, another improvement and an increase of 4.2\% (Duszyński et al. 2020). The announcement of the epidemic in Poland had a significant impact on many aspects of life in the country, both the social life of Poles and their financial situation changed. Many industries also plagued with problems, these include medicine, catering, sport, or tourism. It is also worth mentioning a big problem in the real estate rental industry. They recorded a large decline in the price of rented flats or rooms in many Polish cities due to a smaller number of students because of the remote learning (Kaźmierczak 2020), the largest decreases were recorded in the cities of academic, as Poznan, Warsaw and Rzeszow (Medicus Institute 2019).

Cracow is the capital of the province of Malopolska with an area of $327 \mathrm{~km}^{2}$ and 779115 citizens (as of 12.31.2019) (Piątkowski 2019). Cracow occupies 2.2\% of the Malopolska voivodship area, but in terms of population it is about $23 \%$ of the voivodship (Kałkowski 2005). This indicates a very large real estate market accumulated on a small area. The city consists of 4 main, "large" districts (Krowodrza, Nowa Huta, Srodmiescie and Podgorze districts, Figure 1).

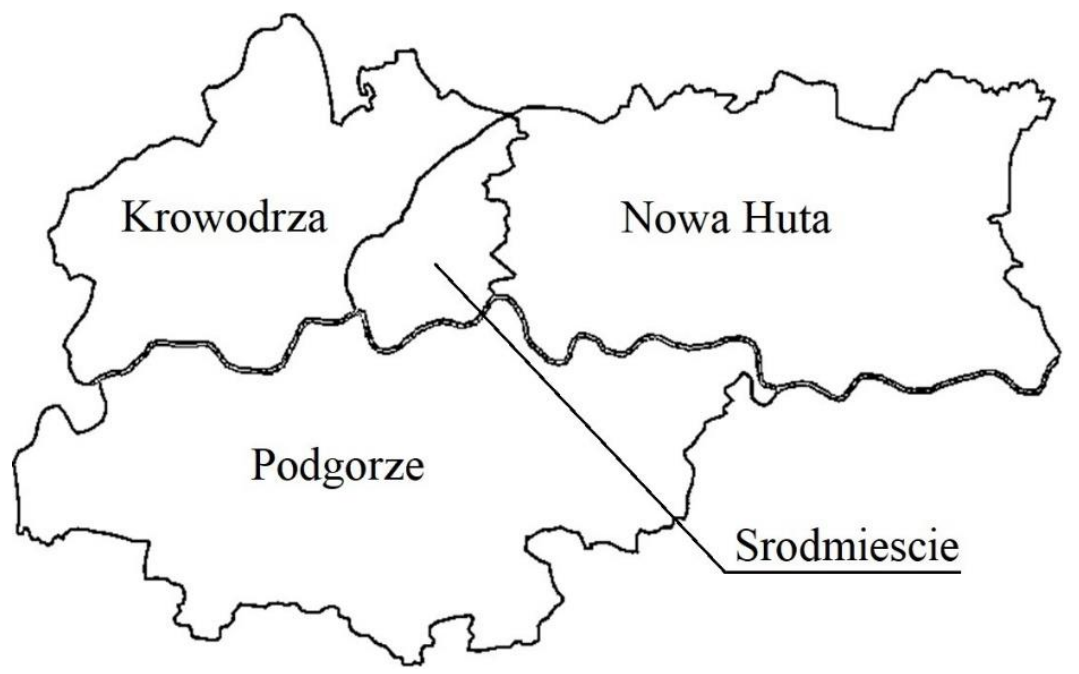

Fig. 1. Distribution of the four main Cracow's districts Source: Skowron 2020

City might be also divided by 18 , a smaller districts, the so-called local government (UMK 2018). The information on the area and number of inhabitants in each main district presents in Table 1. 
Tab. 1

Information on the districts of Cracow

\begin{tabular}{|l|r|r|}
\hline The name of the district & Number of residents & Area $\left[\mathrm{km}^{2}\right]$ \\
\hline Srodmiescie & 106,949 & 17,851 \\
\hline Krowodrza & 146,442 & 66,969 \\
\hline Podgorze & 262,050 & 130,889 \\
\hline Nowa Huta & 193,979 & 110,771 \\
\hline Total & 709,400 & 326,839 \\
\hline
\end{tabular}

In first half of 2020 in Cracow, a maximum decrease in interest in renting was noted at the level of - $49.8 \%$ (Drogomirecki 2020). So, the question arises whether the real estate market is also experiencing a kind of crisis? For this purpose, an analysis of the real estate market in Cracow was carried out to determine changes in the market for the sale of apartments and single-family houses in the city. Number of transactions and transaction prices were analysed according to the types of real estate for the first 3 quarters of 2017-2020 years. This is due to the delay with which the databases of real estate price and value registers are supplemented with data from the real estate market. In connection with the $4^{\text {th }}$ quarter of 2020 as a not fully updated, not taken into consideration. To compare with the three previous years, which also removed the quarter. This was to eliminate the factor related to fluctuations in the real estate market caused by the period of the year, usually the number of real estate transactions decreases in the winter.

Statistical data on real estate turnover in Cracow are currently available only for the years 2017 and 2018, for the remaining years they have not been published yet (Chełstowska 2018). In 2017, apartments on the primary market achieved a high pace of sales, as evidenced by reduced number of construction investments. The average price of apartments was PLN (Polish Zloty) 7,000 per square meter, which increased by $12 \%$ compared to the previous year. On the secondary market, the average price of a flat exceeded PLN 300,000, and the average floor space of the flats purchased was $50 \mathrm{~m}^{2}$. Year 2018 is still characterized by high demand on the primary housing market, but, similarly to 2017, the number of construction investments decreased. This was mainly due to the decreasing number of land available for investment in the city. Average price per square meter fell slightly but continue oscillate around the vicinity of 7,000 PLN per square meter. There were no major changes on the secondary market. The average price and floor space of flats remained at the levels of PLN 300,000 and PLN $50 \mathrm{~m}^{2}$ respectively, similar to the previous year (Chełstowska 2019). According to the (Majewski 2015) there is no best time to buy a flat. Each of the annual quarters has advantages and disadvantages regarding the decision to buy an apartment. These features balance each other, so it is impossible to say which month is the best time to buy.

In this study, data were obtained from the Registry of Prices and Values Property (RPVP, polish Rejestr Cen i Wartości Nieruchomości) available in Cracow City Hall; as of 29 December 2020), for the years 2017-2020. This period results from the rules in force in the City Hall, which allowed employees to provide only a 4-year period of data for work purposes. The number of transactions was 22,164 (17,884 apartments and 4,280 single-family houses). The data was compared in terms of the location of properties in a given district, the year of transaction and average prices. The paper presents the data contained in the obtained real estate database and the scope of their use. Based on the data, charts showing the results of individual analyses were drawn together with comments. Finally, a short summary is written, and the conclusions drawn are described. 


\section{DATA AND METHODS}

The work transactional data obtained for the two types of property traded for single-family houses and apartments. Information about it has been assigned to each transaction. The database contained information in the number of 61 items, including e.g.: date of the contract, transaction price, type of rights to the real estate or type of transaction.

6 out of 61 attributes were used in the work (Table 2), based on which the analyses were carried out. Based on address specified districts in which there is data of real estate, to analyse the number of transactions for each of the main areas of the city. It is worth mentioning that these data do not include transactions from December 2020, so in fact the exact period of the analysis applies to the period from January 2017 to November 2020. In the case of 2020, the exact number of transactions would not be known until April 2021. For the results to be reliable, the transactions concluded in the four quarters of each year were excluded from the analysis. After receiving the data, the database was first divided into individual years, and then into individual quarters. The next step was to filter incomplete and missing data.

Tab. 2 .

Used attributes from RPVP

\begin{tabular}{|l|l|}
\hline Information/Data & Purpose of use \\
\hline Contract date & Specifying the year and quarter of the transaction date \\
\hline Address & Assignment to district \\
\hline Type of real estate & Selection of transactions from a given type of market \\
\hline Buyer and seller & Selection of pages \\
\hline Transaction price & Determining the average transaction price per square meter \\
\hline Area & \\
\hline
\end{tabular}

While working with the database, single errors in information about transactions were noticed, which did not affect the size of the database, and some of them (such as the address) were missing. Incorrect and incomplete data have been removed from the analysed database. Then, a 4-step filtering of the 'raw' database was performed:

(1) transactions removal from the fourth quarter in each year

(2) leaving only transactions between natural persons, excluding any form of legal person and related

(3) transactions on the free market, excluding any form tender, discounted price, etc.

(4) transactions with a $1 / 1$ share in the entire property

The numerical analysis of the remaining data is presented in Table 3, the initial values are 17,884 and 4,280 sales transactions of apartments and single-family houses, respectively.

The final number of transactions after applying the above-mentioned 4 filters are 12,045 apartments out of 17,884 at the beginning and 1,004 single-family houses out of 4,280 in the entire base. Thus, the database is the subject of the analysis was a $67.4 \%$ and $23.4 \%$ for apartments and single-family houses databases respectively.

There is no information on the area of single-family houses in the RPVP database, it is available to appraisers after analysing the copies of notarial deeds available at the starost's office. In this connection it was decided to the analysis of average transaction prices and their volatility in the analysed years. This analysis was carried out with the use of a filter for 
removing $10 \%$ of real estates with maximum and minimum prices. There are therefore 897 transactions left for the analysis of average prices.

Tab. 3 .

The applied filters of the original database and the impact on its size

\begin{tabular}{|l|c|c|c|c|}
\hline \multirow{2}{*}{ The filter used } & \multicolumn{2}{|c|}{ One-family houses } & \multicolumn{2}{c|}{ Residential premises } \\
\cline { 2 - 5 } & $\begin{array}{c}\text { Transactions } \\
\text { left }\end{array}$ & $\begin{array}{c}\text { Remaining } \\
\text { percentage of } \\
\text { initial value\% }\end{array}$ & $\begin{array}{c}\text { Transactions } \\
\text { left }\end{array}$ & $\begin{array}{c}\text { Remaining } \\
\text { percentage of } \\
\text { initial value\% }\end{array}$ \\
\hline Initial number of transactions & 4,280 & $100.0 \%$ & 17,884 & $100.0 \%$ \\
\hline $1 / 1$ shares & 2,377 & $55.5 \%$ & 17,250 & $96.4 \%$ \\
\hline $\begin{array}{l}\text { Only transactions between natural } \\
\text { person }\end{array}$ & 1,428 & $33.4 \%$ & 15,386 & $86.0 \%$ \\
\hline Transactions only in the free market & 1,316 & $30.7 \%$ & 15,332 & $85.7 \%$ \\
\hline $\begin{array}{l}\text { Removal of transactions from the } \\
\text { fourth quarter }\end{array}$ & 1,004 & $23.4 \%$ & 12,045 & $67.4 \%$ \\
\hline
\end{tabular}

The price per square meter of residential premises in the period 2017-2020 was also analysed (including the fourth quarter), based on the transaction price and the area of the premises. There were large discrepancies in the price per square meter in the database, and for the results to be more reliable, outliers were excluded from the analysis. In the first place, transactions concerning premises with an area smaller than $12 \mathrm{~m}^{2}$ and larger than $200 \mathrm{~m}^{2}$ were rejected. They were rejected due to the lack of availability of apartments with an area of less than $12 \mathrm{~m}^{2}$ and apartments with an area of more than $200 \mathrm{~m}^{2}$ were significantly different from other premises, these filters were used based on data from the Otodom portal ("Otodom" 2021), where the smallest area of studio available for sale in the area of Cracow was $12 \mathrm{~m}^{2}$ while the residential premises with an area of $200 \mathrm{~m}^{2}$ were removed as outliers due to the small number available in the base, but mainly due to the price per $\mathrm{m}^{2}$, as they are often luxury apartments or multi-unit flats. The second step was to eliminate residential premises sold for prices outside the range of PLN 80,000 to PLN 1 million. The upper limit of the transaction price was dictated by the elimination of apartments and multi- apartment premises, while the lower limit was the price at which the cheapest flats could be purchased in the TBS system (type of social housing). In the last part of the discarded $10 \%$ of the transactions with the lowest price, and $10 \%$ of the transaction with the highest price transaction as outliers, leaving 14,620 transaction and.

\section{ANALYSE OF THE MARKET}

The results of the transaction analysis for two types of real estate: single-family houses and residential premises are presented in this section, both analyses are divided into 5 types:

(1) Data on the number of transactions in Cracow in the analysed years (Figures 2 and 7).

(2) The number of sales transactions in the city, divided into quarters for each year. In connection with the analysis of the number of transactions carried out in the given annual quarters, transactions from individual months were first selected and compared with the first three quarters of the analysed years. Later, all transactions from all quarters 
in individual years were summed up and these numbers were compared with each other (Figures 3 and 8).

(3) Changes in the average transaction price for single-family houses (Figure 4) and the average price per square meter of housing (Figure 9). In the case of single-family houses, transactions in the price range from PLN 400,000-2,000,000 were considered from the database. When analysing apartments premises, apartments in the price range of 80,000-1,000,000 PLN were considered. In this way, the transaction prices were similar, and all the individual analysed periods were reliable. The analysed periods are the quarters of individual years.

(4) Number of transactions in particular years and districts (Figures 5 and 10) as presented for better interpretation on the map of Cracow. The location in relation to the district on the map of Cracow was determined based on the address. Using the data prepared in this way, an analysis was carried out in relation to the number of transactions carried out depending on the quarter of a given year and the district.

(5) Statement of the number of transactions in individual quarters for all years (Figures 6 and 11).

\subsection{Single-family houses}

Figure 2 shows how the number of transactions regarding single-family houses in the city has changed over the analysed years. In the year around in 2017 and 2018 the number of transactions concluded during the year does not differ significantly from each other. The difference between them is only 8 contracts. The year 2019 is also a similar number of transactions as in previous years. In 2020 there was a marked decrease in the number of transactions compared to 2018 or 2019. For example, in the year 2020 in Cracow reported only $64.6 \%$ of transactions in the year before, which can be explained primarily situation pandemic in the country.

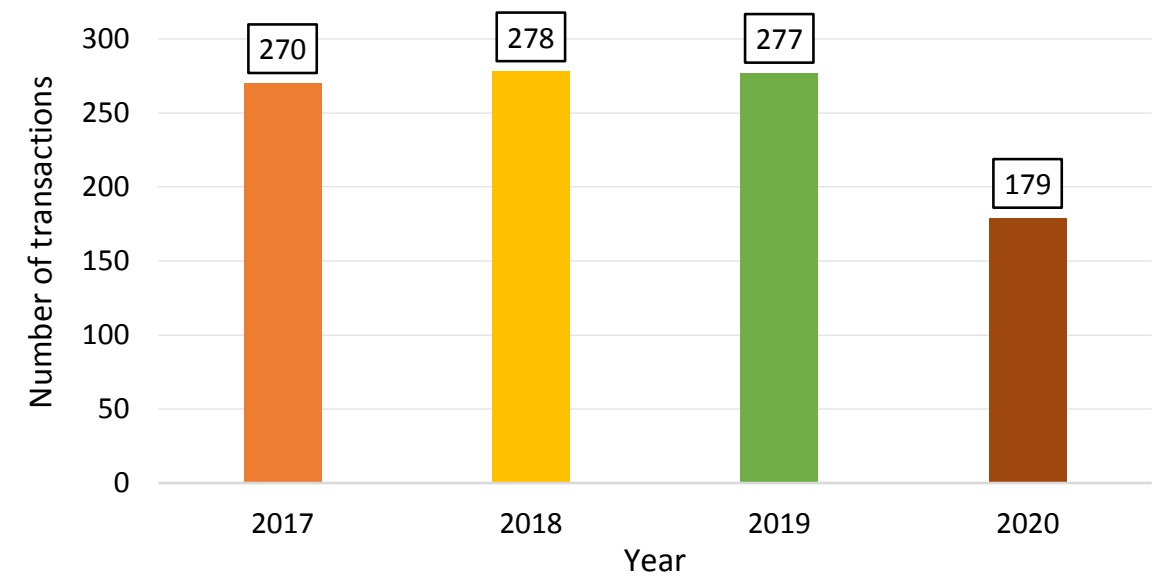

Fig. 2. Number of transactions regarding the sale of single-family houses in Cracow in the analysed years for quarters I-III

Each quarter years 2017-2019 noticeable and a similar number of transactions (Figure 3), only for the year 2020 the number of transactions in each quarter is the smallest. The first quarter is characterized by a similar number of contracts each year. The other two quarters is already a large difference between 2020, and other years. The year 2019 is characterized by 
the highest sales in values I and III. Quarter III is the smallest total number of transactions in the years 2017-2020.

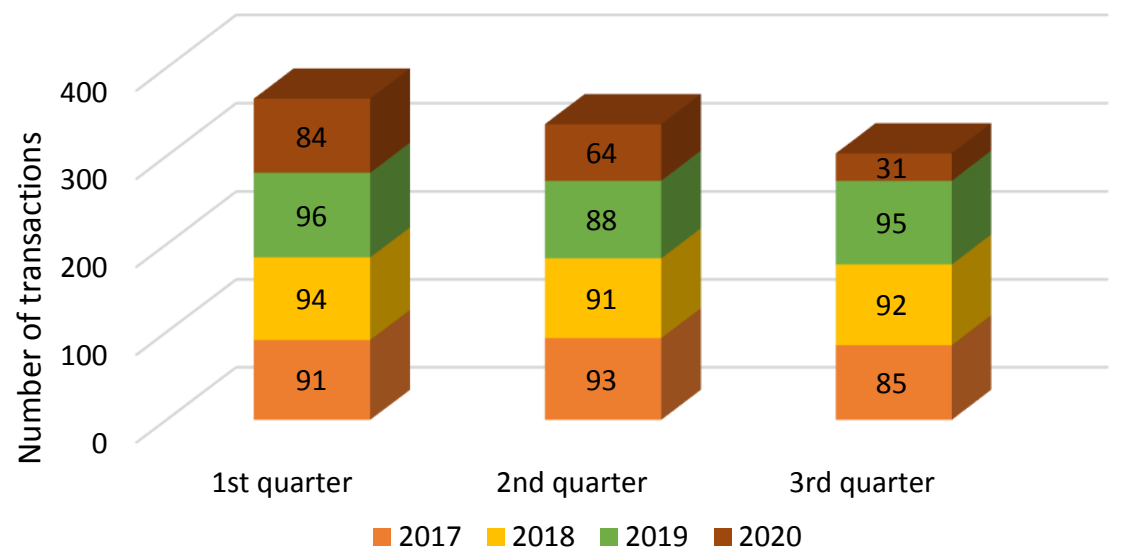

Fig. 3. The number of transactions for the sale of single-family houses in Cracow, broken down by years for each of the quarters

The average transaction price in the city is highly diversified (Figure 4). It is impossible to say that prices are rising or falling uniformly over the months. 2017 saw clear differences in transaction prices. From the fourth quarter of 2017, prices went up. In the second quarter of 2018 there was a slight drop in prices, however, three months later, transaction prices were rising again, and desired for the second quarter of 2019, when prices fell slightly again, to then grow again. Another correction took place in the second quarter of 2020, only to increase again in the next quarter. Price chart indicates the trend and points to the fact that at the end of 2020 and in subsequent years, the transaction price will grow. Shows that that the pandemic is not reflected in the decline in the average price for a house family in Cracow.

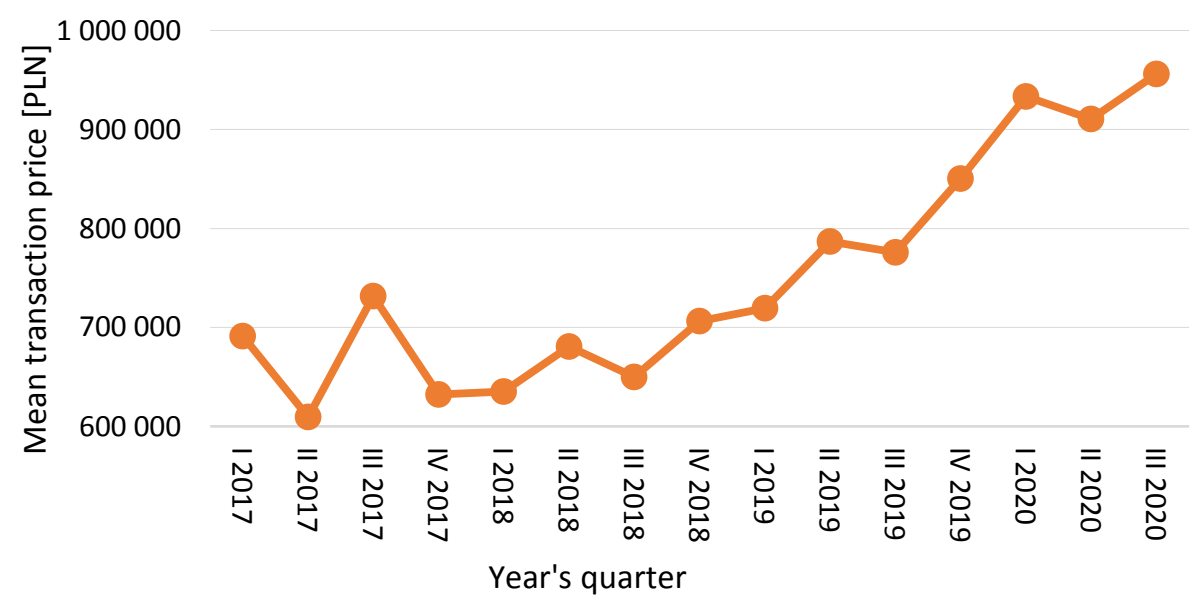

Fig. 4. The average transaction price for the sale of single-family houses in Cracow in particular periods 
Numbers of transaction by year and city districts shows the Figure 5. In each year Podgorze was characterized by the greatest number of transactions, and the Downtown smallest \pm which mainly results from the surface, number of inhabitants and investment attractiveness. The year 2020 is distinguished by the lowest total number of transactions in each district. The figure seen you, that the initial months of the year 2020 showed a similar number of transactions as the first months of previous years. In addition, in 2020, in each district, after Q1, the number of transactions decreased gradually, where Q3 this year indicated the lowest number of signed purchase contracts.
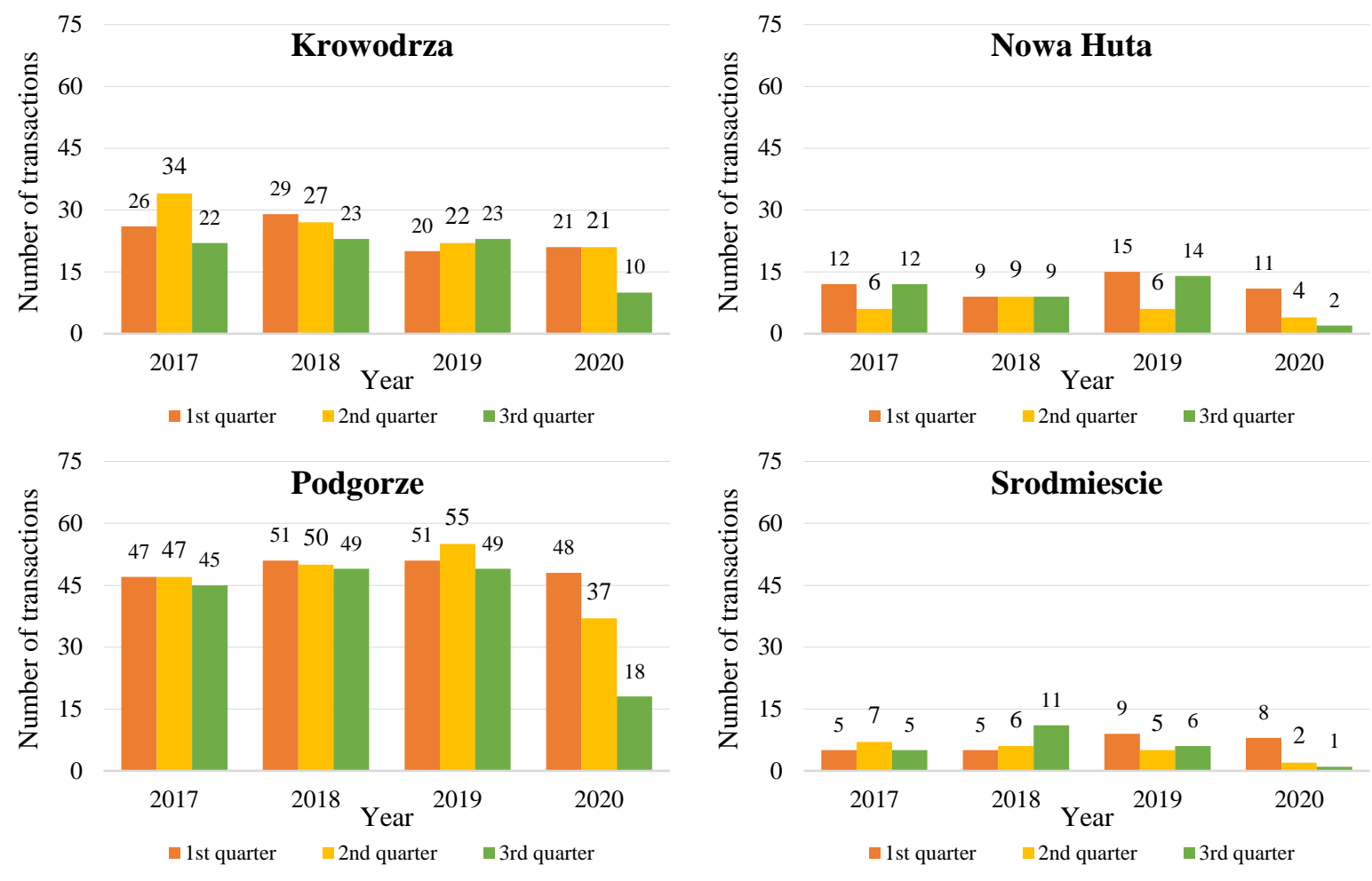

Fig. 5. Number of transactions for the sale of single-family houses in Cracow in each district for the analysed years.

Source: Skowron 2020

In given quarters, in specific years - excluding 2020 - the differences between them are insignificant (Figure 6). In the year 2017 the largest number of agreements were signed in and I quarter, and in the first quarter of the third smallest. In 2018, purchase and sale transactions in the first quarter were concluded in the highest number. The next year (2019) all reached the quarter comparable figures s homes sold. It is worth mentioning that the differences between the quarters in 2017-2019 are insignificant and reach a level of several percent. Only the year 2020 indicates a large drop in sales of single-family houses in the city after the first quarter.

The COVID-19 virus could have contributed to a significant difference between the number of transactions in the second and the first quarter of 2020. The country announced the epidemic in March, i.e., at the end of the first quarter, hence the sudden drop after the first quarter. Considering the tendency of sales decline in 2020, the forecast for the last quarter predicts a lower number of transactions than in the third quarter. So, the fourth quarter is unlikely to exceed the fifty-transaction threshold. 


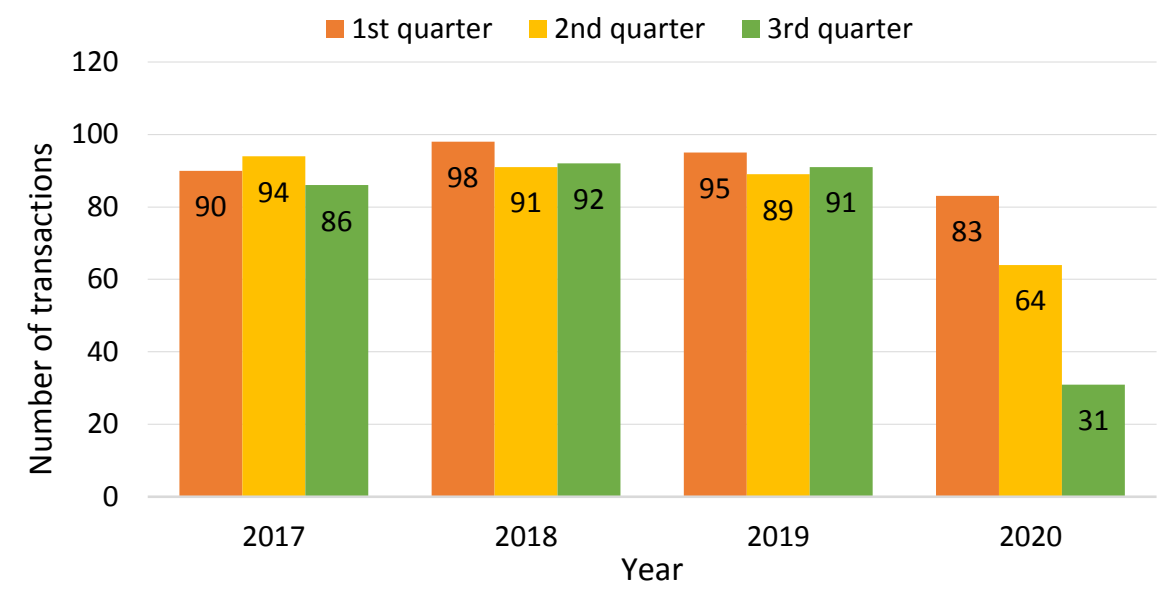

Fig. 6. Number of transactions for the sale of single-family houses in Cracow each year and quarter

\subsection{Apartments}

The results of individual analyses concerning residential premises are presented in a similar way to the diagram of the analysis of single-family houses presented in subsection 3.1. A constant increase in the sale of flats in particular years is noticeable. However, 2020 shows a significantly reduced interest in buying a home, as shown in Figure 7. The differences between 2017 and 2018, and 2018 and 2019, are around 400 transactions. The huge drop in the number of transactions from 2019 to 2020 of exactly $44.8 \%$ is due to the impact of the virus on the real estate market.

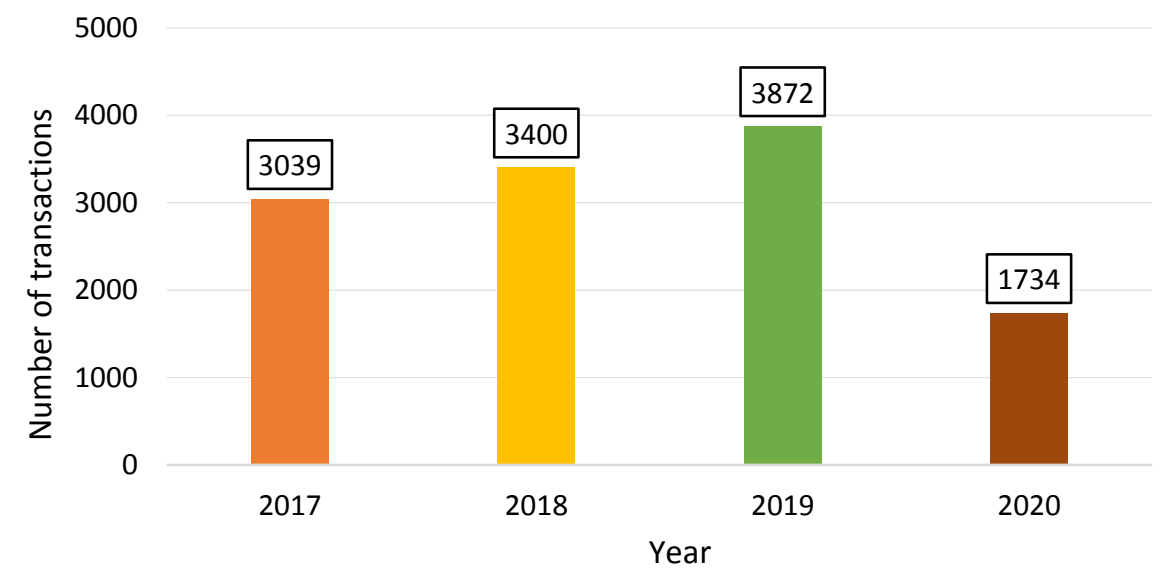

Fig. 7. The number of transactions related to the sale of residential premises in Cracow

Comparing the analysed years, a decrease in the number of transactions for each quarter in 2020 is clearly visible, only in Q1 this number (861) is like that of 2017 (932). The year 2019 is a noticeable difference in the number of concluded contracts (between other years), where this year is characterized by the highest number in each of the quarters. Quarter I have a total of 3,927 contracts, quarter II - 3,864 transactions, and quarter III - 4,524 concluded contracts (the sum of the number of transactions in each quarter of each year). The differences between 
Q1 and Q2 are 63 contracts, in Q1 and Q3 597 concluded contracts and between Q2 and Q3 660 transactions. These discrepancies are in the range of $0.5-5.4 \%$ in relation to the sum of all analysed transactions (Figure 8).

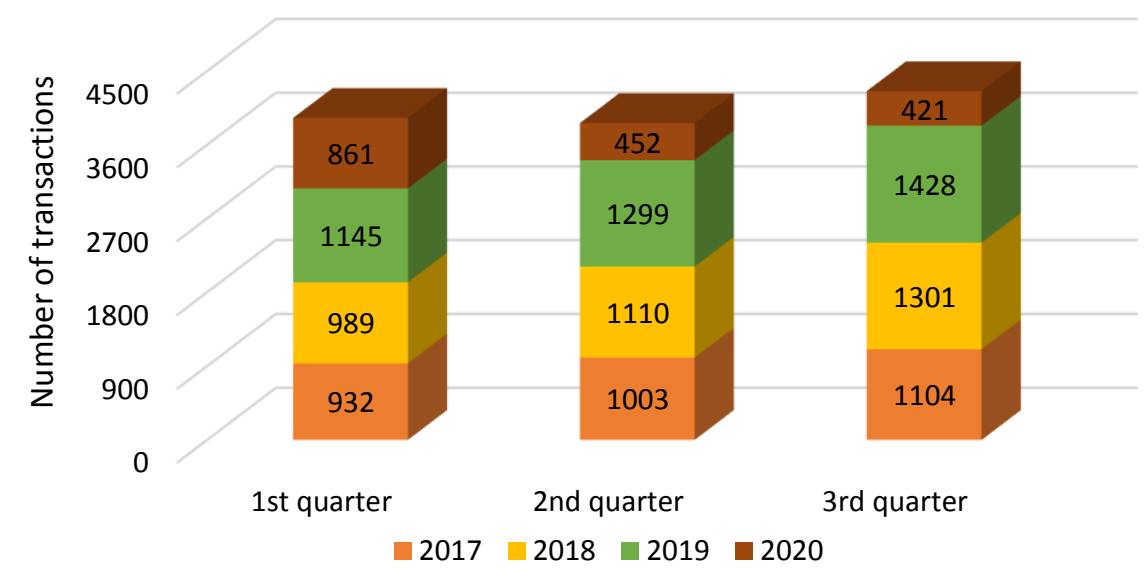

Fig. 8. The number of transactions concerning the sale of residential premises in Cracow divided by quarters

After analysing the average transaction prices per square meter of a dwelling in the quarters of individual years, a constant increase in average prices was noticeable, which is shown by Figure 9. The source of the appeal cannot be found. In the years 2017-2020, there was once a decrease in the average prices of a square meter of a dwelling. It took place in the fourth quarter of 2017. The end of 2020 shows a slight but steady rise in average prices per square meter. This heralds that at the turn of 2020 and 2021, the value of a square meter in Cracow will increase.

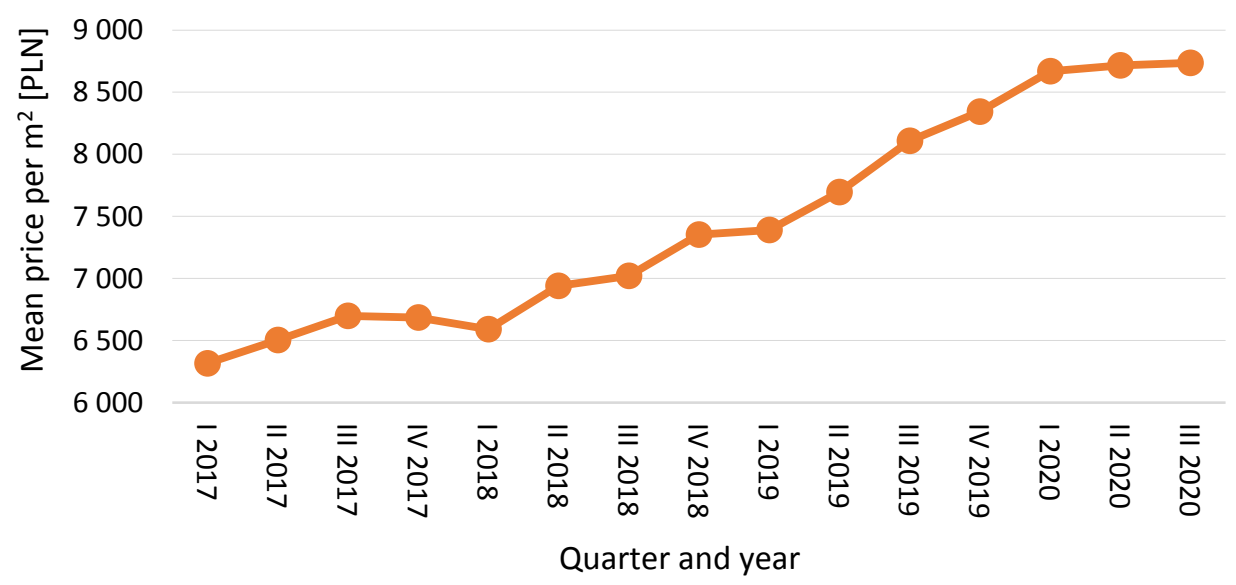

Fig. 9. Average transaction price for the sale of residential premises in Cracow in individual periods 
The tendency to buy flats in districts in the case of single-family houses shows that Nowa Huta enjoys the least interest, and Podgorze - the largest (Figure 10). As in the case of singlefamily houses, 2020 is characterized by the lowest number of transactions during the year. Q1 in 2020 was characterized by a similar level of purchased residential premises every Q1 in previous years. The next two quarters of 2020 are a continuous decline in the number of concluded contracts. The exception is Podgorze, where in 2020 the number of transactions in Q3 is greater than in Q2 of the same year.
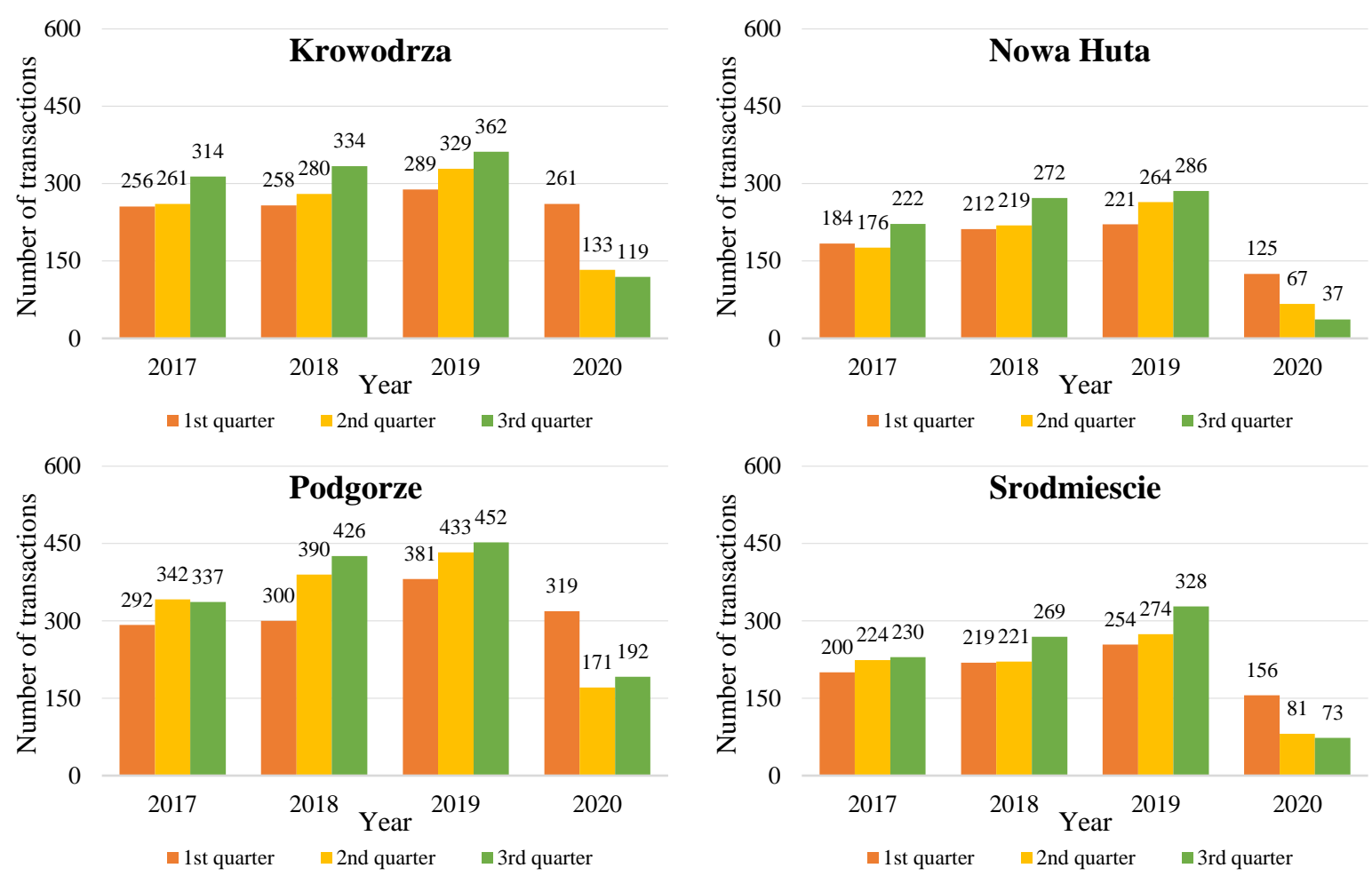

Fig. 10. Number of transactions regarding the sale of apartments in Cracow in each district for the analysed years.

Source: Skowron 2020

Each analysed year in the 2017-2019 period shows a regular increase in the number of contracts concluded over the months. However, this pattern does not apply to 2020, where the number of transactions decreased over time (Figure 11). In the last analysed year, only the 1st quarter showed a number with a slight difference compared to the 1st quarters of the previous years.

After the first quarter of 2020, restrictions in relation to the COVID-19 virus began to apply in the country, which could have a significant impact on the situation related to the purchase of apartments. Each year, the regularity of sales growth over the months is noticeable. Only the year 2020 shows a regular decrease in the number of signed contracts. 


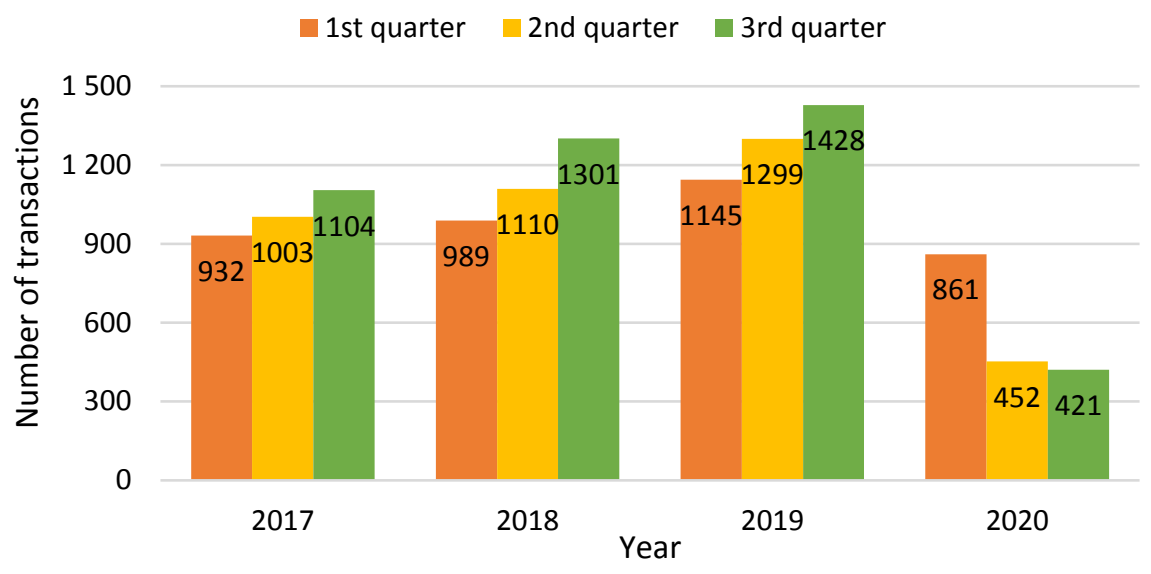

Fig. 11. Number of transactions related to the sale of residential premises in Cracow each year and in a particular quarter

\section{SUMMARY AND CONCLUSIONS}

The aim of this study was to analyse the impact of the COVID-19 coronavirus pandemic on the number of purchase and sale transactions and prices of apartments and single-family houses in Cracow. A pandemic broke out in 2020 and a pandemic state was declared in late March of that year. Many restrictions concerning social life and in the field of economy were introduced. At the end of the year, a national quarantine was introduced, which still prevented and blocked the development of many areas of culture, science, and economy. Due to delays in submitting copies of notarial deeds by notaries to starosts, the data for the fourth quarter was incomplete for 2020. Therefore, the analysis of the number of transactions for 2017-2020 covered only the quarters 1-3. The collected transaction database for Cracow included 22,164 transactions, and after applying data filtration, the database decreased to 13,049 transactions (58.9\% of the initial number). This sum consisted of 12,045 housing transactions and 1,004 single-family housing transactions. The filtration process was three-stage and included: only purchase and sale agreements between natural persons, only free market transactions and transactions concluded only in I, II and III quarter of each year. The work includes analyses of the number of transactions, average transaction prices (single-family buildings) and average prices per square meter (residential premises). Based on the analysis, the following conclusions were drawn:

- The beginning of the national quarantine period in 2020 had a significant impact on the number of purchase and sale transactions of apartments and residential buildings. There was a significant drop in the number of contracts signed after the first quarter of this year. The quarantine in the country was introduced in March, so during the analysis, the key factor was the difference between the first and second quarter of 2020. The difference between them was $48.9 \%$ for residential premises and $36.9 \%$ for single-family houses. Only the first quarter of this year was characterized by the number of transactions, which did not differ significantly from the number of transactions in the remaining quarters of the analysed years. 
- The number of transactions in 2020 was more than half lower than the number of transactions concluded in the previous years analysed (2017-2019). An example may be 2020 comparable to 2018 on the residential premises market, where the number of 1,734 transactions is only about $51 \%$ of the transactions concluded in 2018 . This comparison on the single-family house market showed a difference equal to $64.6 \%$.

- The analysis of the number of transactions in individual quarters in 2017-2019 did not show any significant changes between individual (subsequent) quarters for both databases. Thus, it was shown for the analysed data that the season had no impact on the number of transactions. The only exception is 2020 , but it is related to the epidemic situation in the country.

- The average transaction price for a single-family house in Cracow over the analysed years showed a slight upward trend, with small fluctuations between consecutive quarters. 2017 saw an alternating shift between a sharp rise and a fall in prices. 2018 is a year of slight fluctuations in average transaction prices. From 2018 Q3, these prices were rising systematically until the beginning of 2020, where a further decline in prices was recorded. However, three months later, prices were rising again. The COVID-19 virus may have had an impact on the shaping of the transaction price chart, the drop in prices in 2020 could have been caused by lower demand for real estate due to the uncertainty caused by the pandemic. Later, when demand increased, prices may have gone up.

- The situation related to the COVID-19 virus did not have a major impact on the changes in the average price per square meter when it comes to residential premises, which is visible in the constant upward trend in price in Q3 2020, since the beginning of the analysed period, the price per $\mathrm{m} 2$ has been systematically grew every quarter. Only in the first quarter of 2018, there was a single breakdown in the trend line, however, the difference in price was small. The demand for apartments in Cracow is not decreasing, which means that the pandemic has no significant impact on the prices on the Cracow real estate market.

\section{References}

1. Chełstowska Agata. 2018. Cracow Real Estate Market 2017. Department of Strategy, Planning and Monitoring of Investments. Cracow.

2. “Cracow Real Estate Market 2018”. Department of Strategy, Planning and Monitoring of Investments.

3. Drogomirecki Marcin. 2020. "The Real Estate Market in the 1st Half of 2020”. Cracow.

4. Duszyński Jerzy, Aneta Aflet, Anna Ochab-Marcinek, Radosław Owczuk, Krzysztof Pyrć, Magdalena Rosińska, Andrzej Rychard, Tomacz Smiatacz. 2020. "Understand COVID-19." Polish Academy of Sciences Magazine 64(4): 38.

5. Kałkowski Leszek. 2005. "The Size and Structure of the Cracow Real Estate Market". Available at: https://r.uek.krakow.pl/bitstream/123456789/1565/1/87127792.pdf.

6. Kaźmierczak Marcin. 2020. "Apartments in Times of a Pandemic. 5 Visible Trends". Bankier.Pl.

7. Kostyńska Marlena. 2020. "COVID-19 - Causes, Symptoms, Course, Treatment”. Medonet. Available at: https://www.medonet.pl/choroby-od-a-do-z/choroby-ukladuoddechowego-i-alergie,covid-19---przyczyny--objawy--przebieg-leczenie, artykul,61168587.html.

8. Majewski Piotr. 2015. "The Best and Worst Times of the Year to Buy an Apartment". Morizon.Pl. 
9. Medicus Institute. 2019. "26 of the Most Academic Cities in Poland". Pomaturze.Pl.

10. "Otodom." 2021. Available at: https://www.otodom.pl/.

11. Piątkowski Wojciech. 2019. "Cracow in Numbers 2019”. Cracow.

12. Skowron Grzegorz. 2020. "Map of Cracow Districts".

13. UMK. 2018. "Current Local Government Districts of Cracow". Available at: https://www.poczetkrakowski.pl/maleojczyzny/iii-aktualne-dzielnice-samorzadowekrakowa/.

Received 03.10.2021; accepted in revised form 09.12.2021

$$
\text { (c) (i) }
$$

Scientific Journal of Silesian University of Technology. Series Transport is licensed under a Creative Commons Attribution 4.0 International License 